\title{
Design and Control of Electrical Motor Drives
}

\author{
Tian-Hua Liu (1)
}

check for updates

Citation: Liu, T.-H. Design and Control of Electrical Motor Drives. Energies 2021, 14, 7717. https:// doi.org/10.3390/en14227717

Received: 3 November 2021 Accepted: 12 November 2021 Published: 18 November 2021

Publisher's Note: MDPI stays neutral with regard to jurisdictional claims in published maps and institutional affiliations.

Copyright: (C) 2021 by the author. Licensee MDPI, Basel, Switzerland. This article is an open access article distributed under the terms and conditions of the Creative Commons Attribution (CC BY) license (https:// creativecommons.org/licenses/by/ $4.0 /)$.
Department of Electrical Engineering, National Taiwan University of Science and Technology, Taipei 106, Taiwan; Liu@mail.ntust.edu.tw

\section{Introduction}

This Special Issue contains the successful invited submissions [1-11] to a Special Issue of Energies on the subject of the "Design and Control of Electrical Motor Drives". Electrical motor drives are widely used in industry, automation, transportation, and home appliances. Indeed, rolling mills, machine tools, high-speed trains, subway systems, elevators, electric vehicles, and air conditioners all depend on electrical motor drives. However, the production of effective and practical motors and drives requires flexibility in the regulation of current, torque, flux, acceleration, position, and speed. Without proper modeling, drive, and control, these motor drive systems cannot function effectively.

To address these issues, we need to focus on the design, modeling, drive, and control of different types of motors, such as induction motors, permanent synchronous motors, brushless DC motors, DC motors, synchronous reluctance motors, switched reluctance motors, flux-switching motors, linear motors, and step motors. Therefore, relevant research topics in this field of study include modeling electrical motor drives, both in transient and in steady state, and designing control methods based on novel control strategies (e.g., PI controllers, fuzzy logic controllers, neural network controllers, predictive controllers, adaptive controllers, nonlinear controllers, etc.), with particular attention paid to transient responses, load disturbances, fault tolerance, and multi-motor drive techniques.

This Special Issue encourages and invites original contributions regarding the recent developments and ideas in motor design, motor drive, and motor control. Potential research topics include, but are not limited to, the following: motor design, field-oriented control, torque control, reliability improvement, advanced controllers for motor drive systems, DSP-based sensorless motor drive systems, high-performance motor drive systems, highefficiency motor drive systems, and practical applications of motor drive systems.

To make it clear, the topics of interest for the call for papers included, but were not limited to, the following:

- Induction motor (IM) and drive;

- $\quad$ Permanent magnet synchronous motor (PMSM) and drive;

- Synchronous reluctance motor and drive;

- Switched reluctance motor and drive;

- Switching flux motor and drive;

- Linear motor and control;

- $\quad$ Step motor and control;

- Fault-tolerant drive;

- DSP-based motor drive;

- High-efficiency motor and drive;

- Sensorless drive system.

The published papers fell into five general areas-DC motor drives, PMSM motor drives, induction motor drives, flux-switching motor drives, and synchronous reluctance motor drives. The details are shown in Table 1. 
Table 1. The broad spectrum of published papers.

\begin{tabular}{|c|c|c|c|c|c|}
\hline Detailst Sub-Topics & $\begin{array}{l}\text { DC Motor } \\
\text { Drives }\end{array}$ & $\begin{array}{c}\text { Induction Motor } \\
\text { Drives }\end{array}$ & $\begin{array}{l}\text { Syncronous } \\
\text { Reluctance } \\
\text { Motor Drives }\end{array}$ & PMSM Motor Drives & $\begin{array}{c}\text { Flux-Switching } \\
\text { Motor Drives }\end{array}$ \\
\hline The Main Contents & $\begin{array}{ll}\text { - } & \text { Inverse } \\
\text { Optimal } \\
\text { Control } \\
\text { - } \quad \text { State } \\
\text { Derivative } \\
\text { Space } \\
\text { Nonlinear } \\
\text { Control }\end{array}$ & $\begin{array}{ll}\text { - } & \text { Fault- } \\
\text { Tolerant } \\
\text { Control } \\
\text { - } \quad \text { Three Level } \\
\text { Inverter } \\
\text { - Star-Delta } \\
\text { Starting }\end{array}$ & $\begin{array}{ll}-\quad & \text { Rotor } \\
\text { Position } \\
\text { Estimating } \\
\text { - } \quad \text { Predictive } \\
\text { Control }\end{array}$ & $\begin{array}{ll}\text { - } & \text { Sensorless } \\
\text { - } & \text { High-Speed Control } \\
\text { - } & \text { Backstepping } \\
& \text { Control } \\
\text { - } & \text { Low Inductance } \\
& \text { PMSM Control } \\
\text { - } & \text { FPGA-Based } \\
\text { - } & \text { Control } \\
\text { Harmonic Current } \\
\text { Suppression }\end{array}$ & $\begin{array}{ll}- & \text { Sensorless } \\
\text { - } & \text { Predictive } \\
\text { Control }\end{array}$ \\
\hline
\end{tabular}

\section{A Short Review of the Contributions in This Issue}

Eleven papers were accepted for this Special Issue. Lee et al. [1] proposed that inverse optimal control in a state derivative space system in DC motor tracking control, without using a tachometer, but using the feedback of state derivatives, could reduce cost. In the paper [2] investigated by Kao et al., current harmonic control improved the three-phase current THD from 5.3\% to 2.3\%. Tsai et al. [3] implemented FPGA-based current control and SVPWM ASIC for AC motor drives, which could reduce power loss by $33 \%$ compared to a conventional method. Itajiba et al. investigated a Y- $\Delta$ starting of induction motors. By using a statistical method, the experimental results that used two forms of $\Delta$ connection were studied. Chao et al. [5] proposed an intelligent fault diagnosis drive system to improve the reliability of inverters. A real-time, smooth switching method was used for fault-tolerant control. Kasper et al. [6] investigated optimal torque feedforward and modal current feedback control for low-inductance PM motors. The method reduced torque ripples and motor losses significantly. Liu et al. [7] designed a high-speed PM motor, focused on rotor unbalanced radial forces, rotor power losses, and rotor mechanical strength. Lin et al. [8] used backstepping control to improve the chattering phenomenon of AC motor drives. In addition, the backstepping control could reduce nonlinear uncertaintyeffects. Mubarok et al. [9] implemented a wide-adjustable sensorless IPMSM speed drive system based on current deviation detection under spacevector modulation. By using the proposed method, the IPMSM motor could be operated from $0 \mathrm{r} / \mathrm{min}$ to $3000 \mathrm{r} / \mathrm{min}$. Liu et al. [10] proposed three types of predictive controllers for sensorless flux-switching motor drive systems. An estimated rotor position method that had nearly \pm 2 electrical degrees was developed. The adjustable speed range was from $4 \mathrm{r} / \mathrm{min}$ to $1500 \mathrm{r} / \mathrm{min}$. Finally, Liu et al. investigated sensorless synchronous reluctance motor drive systems. A rotor position observer that was based on motor parameters was developed. The experimental results showed that the drive system could be adjusted from $30 \mathrm{r} / \mathrm{min}$ to $1800 \mathrm{r} / \mathrm{min}$, with good dynamic responses.

We found the task of editing and selecting papers for this collection to be both interesting and rewarding. We would like to thank the authors, staff, and reviewers for their effort and time.

\section{References}

1. Lee, F.C.; Tseng, Y.W.; Wu, R.C.; Chen, W.C.; Chen, C.S. Inverse Optimal Control in State Derivative Space with Applications in Motor Control. Energies 2021, 14, 1775. [CrossRef]

2. Kao, W.T.; Hwang, J.C.; Liu, J.E. Development of Three-Phase Permanent-Magnet Synchronous Motor Drive with Strategy to Suppress Harmonic Current. Energies 2021, 14, 1583. [CrossRef]

3. Tsai, M.F.; Tseng, C.S.; Chen, P.J. Implementation of an FPGA-Based Current Control and SVPWM ASIC with Asymmetric Five Segment Switching Scheme for AC Motor Drives. Energies 2021, 14, 1462. [CrossRef]

4. Itajiba, J.A.; Varnier, C.A.C.; Cabral, S.H.L.; Stefenon, S.F.; Leithardt, V.R.Q.; Ovejero, R.G.; Neid, A.; Yow, K.C. Experimental Comparison of Preferential vs. Common Delta Connections for the Star-Delta Starting of Induction Motors. Energies 2021, 14, 1318. [CrossRef] 
5. Chao, K.H.; Ke, C.H. Fault Diagnosis and Tolerant Control of Three-Level Neutral-Point Clamped Inverters in Motor Drives. Energies 2020, 13, 6302. [CrossRef]

6. Roland, K.; Golovakha, D. Combined Optimal Torque Feedforward and Modal Current Feedback Control for Low Inductance PM Motors. Energies 2020, 13, 6184.

7. Liu, N.W.; Hwang, K.Y.; Yang, S.C.; Lee, F.C.; Liu, C.J. Design of High-speed Permanent Magnet Motor Considering Rotor Radial Force and Motor Losses. Energies 2020, 13, 5872. [CrossRef]

8. Lin, C.H. Permanent-Magnet Synchronous Motor Drive System Using Backstepping Control with Three Adaptive Rules and Revised Recurring Sieved Pollaczek Polynomials Neural Network with Reformed Grey Wolf Optimization and Recoupled Controller. Energies 2020, 13, 5870. [CrossRef]

9. Mubarok, M.S.; Liu, T.H.; Tsai, C.Y.; Wei, Z.Y. A Wide Adjustable Sensorless IPMSM Speed Drive Based on Current Deviation Detection under Space-Vector Modulation. Energies 2020, 13, 4431. [CrossRef]

10. Liu, T.H.; Mubarok, M.S.; Xu, Y.H. Design and Implementation of Position Sensorless Field-Excited Flux-Switching Motor Drive Systems. Energies 2020, 13, 3672. [CrossRef]

11. Liu, T.H.; Ahmad, S.; Mubarok, M.S.; Chen, J.Y. Simulation and Implementation of Predictive Speed Controller and Position Observer for Sensorless Synchronous Reluctance Motors. Energies 2020, 13, 2712. [CrossRef] 